ISBN 978-93-84468-86-6

2016 International Research Conference on Practices in Law Business and Education

(PLBE-16)

Pattaya (Thailand) Dec. 16-17, 2016

\title{
The Relationship between Consolidated Financial Statement and Firm Performance
}

\author{
Prof. Dr. Turgut ÇÜRÜK and Res. Asst. Ayşe TANYERİ \\ The Faculty of Economics and Administrative Sciences, University of Cukurova, Turkey
}

\begin{abstract}
Company financial statements are the main sources of information for those who make economic decisions about the companies. The companies listed on the stock exchange in Turkey, which used to prepare individual financial statements until 2005, have been preparing only consolidated financial statements in accordance with national accounting and financial reporting standards which were adopted from International standards since then. As the discussions and results of some empirical studies in the literature indicate that impact of consolidated and individual financial statements on the performances of companies are different, this study, focusing on the firms registered with stock exchange in Turkey, attempts to investigate the impact of consolidated financial statements on performance of firms.

This study, using stock price and returns as proxies for performance and equity, net income and total assets as proxies for financial statement information, analyzed the impact of transition from individual (solo) to consolidated financial reporting on firm performance, based on data gathered from 384 firm/years financial statement of the firms listed on the İstanbul Stock Exchange (BIST), covering the eight year (four years pre-consolidation and four years post-consolidation) period. The relationship between proxies used for performance and financial statement information of firms were tested using the Ohlson (1995) valuation model and by running pooled regression analysis. The results show that the financial information obtained from the consolidated financial statements (i.e. equity, net income and total assets) of companies have an impact on their stock price and returns which are proxies used for performance.
\end{abstract}

Keywords: Consolidated financial statements, firm performance.

\section{Introduction}

Financial statements, which reflect financial structure, performance, liquidity and cash position of companiesoperating in capital market, constitute the basis for economic decisions by theusers of such statements.Developmentin Turkish economy, increases in integration with the global economies andglobalization of companies over the years, increased the need for the financial statements providing main source of data for decision making process.Such development ledsignificant changes in ownership structure of companiesand particularly recent yearsmany corporations tend to be structured as compose of numerous separate companies. As a result, the preparation of the consolidated financial statements presented as a single economic unit of the group financial statement consisting of parent firm and subsidiaries has become importantworldwide as well as in Turkey. These developments enforced the companies to comply with the legal requirements set for the preparation of consolidated financial statements in accordance with the Generally Accepted Accounting Principles (GAAP).Turkey has experienced significant changes on the area of accounting over the last decadeand a number of new regulations addressing the preparation of financial statements, which were so much in line with the International Accounting Standards, were introduced. These regulations enforced listed companies on stock exchange in Turkey, which were disclosing only individual (solo, unconsolidated) financial statement until 2005, to prepareconsolidated financial statements in accordance with the Turkish Financial Reporting Standards (TFRS) which were adopted from the International Financial Reporting Standards (IFRS).

It is generally accepted that company financial statements are the main sources of information for those who make economic decisions about the companies. To be able to assess the effect of the information derived from 
financial statements on the decision making process of the users of such statements, particularly the investors, it is necessary to evaluate the performance of the companies. Since the company performance cannot be measured as the performance of engine of a car, some proxieshave been used as an indicator of the company performance in studies evaluating the company performance. Stock price and returns, which reflect the investor's valuation of company performance on stock exchange, are among the most important proxiesreferred in the literature. This is because, the market value of the listed companies at the capital marketare shaped mainly by reaction of the investors to the financial structure and performance of the companies. In the stock exchange where the capital market is efficient, financial information obtained from consolidated financial statements, reflecting financial position and performing results of the group,are expected to be reflected, at least theoretically,in the company's market value.

Considering group firm's aspects, as the performance of companies is evaluated through financial information derived from the consolidated financial statements, one may expect to observe the existence of the relationship between the consolidated financial statements and firm performance.In the literature, a number of studies have been conducted to investigate the relationship between consolidated financial statement and firm performance.

\section{Theoretical Discussions}

The information disclosed in the consolidated financial statements effects the decision making process of investors and other users as long as they are comparable, reflect the true and fair view of the company and satisfy need of users.Given that firm performance that allows to evaluate business as a whole, is affected by many factors surrounding the firms, whether the disclosed financial information on consolidated financial statements have positive or negative impact on economic decision of those who use such statements, performance of the companies needs to be analysed in detail.

The success of users of financial statements on their economic decisions depends so much on the decision taken on the basis of information derived from the consolidated financial statements.If the users evaluate to firm performance regardless of data in consolidated financial statements, expectations regarding the decision to be taken would be sustained. In the words, the consolidated financial statements which provide information about the financial condition and results of operations of the group firms provide opportunity to information user to evaluate the firm performance for instant or a specific period.

There is strong argument and some empirical evidences in the literature suggesting the existence of relationship between firm performance and financial information (Francis and Schipper, 1999, p. 326).An analysis of studies in the literature assessing the relationship between financial statements and firm performancessuggest that the consolidated financial statements have different impact on firm performance (Schiebel, 2006; Klimczak, 2011; Suadiye, 2012; Müller, 2014; etc.). It is interesting to note that while the results of some empirical studies carried out in various countries revealed a positive relationship between consolidated financial statements and performances of companies are positive(Callao Jarne and Lainez, 2007; Jermakowicz, Prather-Kinsey and Wulf, 2007; Goncharovetal., 2009; Aharony et al., 2010; Suadiye, 2012; Sultanoğlu, 2014; Müller, 2014; etc.), some others revealed negative relationship (Schiebel, 2006; Paananen, 2008; Paananen and Lin, 2008; Paglietti, 2009, Klimczak, 2011). Therefore, it may not always possible to claim that the relationship between consolidated financial statements and performance are positive or negative. These conflicting results in the literature could partly be attributed to the different proxies used as an indicator of performance or indicators that were not taken into considerations in the studies.

As the empirical study on companies in Turkey, a developing non-EU member European country, is lacking, this study examined the impact of consolidated financial statements on the performance of companies listed on stock exchange.

\section{Research Methodology}

The objective of this study is to analyze the impact of consolidated financial statements on firm performance. Stock price and stock returns are generallyused as proxies for performance in the most of the studies focused on the factors effecting firm performance in the literature. Furthermore, equity and/or net income derived from financial statementsareused most of the studies as proxy for variables affecting the performance.There are also studies usedtotal assets, operating income, tangible and intangible asset, goodwill, etc. as independent variable (Capkun, CazavanJeny, Jeanjean and Weiss, 2008; Goncharov, Werner and Zimmermann, 2009; Aharony, 
Barniv and Falk, 2010; etc.). In line with the literature, we also identified stock price and stock returns as proxies for performances and equity, net income and total assets as independent variable effecting performance in this study. As the companies listed on the stock exchange in Turkey, which used to prepare individual financial statements until 2005, have been preparing only consolidated financial statements since then, the following main hypothesis was set to test the relationship between consolidated financial statement and firm performance:

$H_{0}$ : the level of relationship between financial information derived from financial statements and performance (stock price and return) of companies listed on BİST İstanbul did not change with the transition to the consolidated financial reporting,

Since two different variables (stock price and returns) were used as proxies for performance, the following two sub-hypothesis were set and tested in this study;

$H_{0}$ 1: the level of relationship between financial information derived from financial statements and performance (stock price) of companies listed on BİST İstanbul did not change with the transition to the consolidated financial reporting,

$H_{0}$ 2: the level of relationship between financial information derived from financial statements and performance (stock return) of companies listed on BİST İstanbul did not change with the transition to the consolidated financial reporting,

The population of this study is consist of firms, consistently listed on the BIST in the years 2000-2009, preparing individual financial statements (unconsolidated) in accordance with national accounting standards until 2005, and consolidated financial statements in accordance with TFRS, which were adopted from International standard,since then.Banks, financial intuitions and insurance companies were excluded because of their different accounting practices.On the basis of these criteria and data obtained from the BIST and Public Disclosure Platform (PDP), 104 companies were identified as the population and 48 were randomly selected as the sample of this study.

The period covered in this study were the 2000-2009 periods including pre and post 2005. The years between 2000-2003 period is determined as pre-consolidation and 2006-2009 as post-consolidation period. 2004 is excluded as it is the year in which inflation accounting was applied and 2005 is also excluded as it was the year for transitionto consolidated financial statements. Data analysed in this study was obtained from the financial statementsof atotal of 384 firm/year (48 firm*8 years: first 4 years are pre-consolidated periods/2000-2003, secondary 4 year are post-consolidated periods/2006-2009).

\section{Empirical Models}

The above hypotheses, formed to test the impact consolidated financial reporting on stock price and returns, were tested with the Ohlson (1995) valuation model widely used in the literature (Hung and Subramanyam, 2007; Paananen, 2008; Türel, 2009; Devalle, Onali and Magarini, 2010; Dobija and Klimczak, 2010; TironTudor and Ratiu, 2010; Agostino, Drago and Silipo, 2011; Khanagha, 2011, Suadiye, 2012; Kargin, 2013; Müller, 2014; etc).

In this study, we formed the following two models for stock price and return, respectively;

$$
P_{i t+1}=\beta_{0}+\beta_{1} * B V P S_{i t}+\beta_{2} * E P S_{i t}+\beta_{3} * T A P S_{i t}+\varepsilon_{i t} \text { (Model 1) }
$$

$P_{i t+l}=$ the stock price per share for firm $\mathrm{i}$ at the timet +1 ,

$B V P S_{i t}=$ equity of firm i at year-end financial statements / share of firm i in year $\mathrm{t}$

$E P S_{i t}=$ net income of firm $\mathrm{i}$ at year-end financial statements / share of firm $\mathrm{i}$ in year $\mathrm{t}$

$T A P S_{i t}=$ total assets of firm $\mathrm{i}$ at year-end financial statements / share of firm $\mathrm{i}$ in year $\mathrm{t}$

Share price is calculated as "average closing share prices" for a month period following the year in which the disclosure of financial statements. Because, using average closing prices of certain day, hasnot the advantage of neutralizing possible daily fluctuations of prices and prevent to make a proper analysis.On the other hand, using average closing price for a certain period of time, instead of using the closing price of a certain day, daily price fluctuations are eliminated (Müller, 2014, p. 977).

In the literature, another performance indicator used widely is "stock return" (Paananen, 2008; Sultanoğlu, 2014; etc). In the study, using the stock return as proxy for performance (dependent variable), analyzed the relationship between consolidated financial and firm performance, the following empirical model was elaborated; 


$$
R_{i t+1}=\beta_{0}+\beta_{1} * B_{V P S}+\beta_{2} * E P S_{i t}+\beta_{3} * T A P S_{i t}+\varepsilon_{i t}(\text { Model 2) }
$$

$R_{i t+l}=$ the stock return per share for firm i at the timet +1 .

For this model, we also computed average closing share returns for a month period following the year in which the disclosure of financial statements.

\section{Data Analysis}

If the data are not normally distributed, the data set can be adapted to a normal distribution through some statistical transformations to make normalization, stabilizing and linearizing of data (Kalayc1, 2006, p. 221). One of these transformations is the logarithmic transformation. This is the most common conversion method, when working with rates and negative skewed distributions (Alpar, 2011, p. 131-134). Due to the negative values of the data set in this study, adding a fixed term of observations and applying the logarithmic transformation of variables, the data are adapted to a normal distribution.

This study, using stock price and returns (dependent variables) as proxies for performance and equity, net income and total assets per share (independent variables)in the models, the relationship among these variables were tested by running pooled regression analysis.

\section{Research findings}

In this study, the impact of the consolidated financial statements on the performance of firm was tested by running two regression models set for pre (2000-2003) and post (2006-2009) consolidated periods.Test results for share price and share return are presented in Table 1 and 2, respectively.

TABLE I Empirical Results for Regression Model 1

\begin{tabular}{|c|c|c|c|c|c|c|}
\hline \multirow{2}{*}{$\begin{array}{l}2000-2003 \\
\text { Variable } \\
\end{array}$} & \multicolumn{6}{|c|}{$P_{i t+1}=\beta_{0}+\beta_{1} * B V P S_{i t}+\beta_{2} * E P S_{i t}+\beta_{3} * T A P S_{i t}+\varepsilon_{i t}($ Model 1) } \\
\hline & Beta & $\mathrm{t}$ & t Sig. & $\mathrm{F}$ & $\mathrm{R}^{2}$ & Adj. $\mathrm{R}^{2}$ \\
\hline BVPS & 0,087 & 0,865 & 0,388 & & & \\
\hline EPS & 0,169 & 1,875 & 0,062 & 11,178 & 0,266 & 0,242 \\
\hline TAPS & 0,335 & 4,432 & 0,000 & $(0,000)^{*}$ & & \\
\hline $2006-2009$ & \multicolumn{6}{|c|}{$P_{i t+l}=\beta_{0}+\beta_{1} * B V P S_{i t}+\beta_{2} * E P S_{i t}+\beta_{3} * T A P S_{i t}+\varepsilon_{i t}$ (Model 1) } \\
\hline Variable & Beta & $\mathrm{t}$ & t Sig. & $\mathrm{F}$ & $\mathrm{R}^{2}$ & Adj. $\mathrm{R}^{2}$ \\
\hline BVPS & 0,345 & 3,865 & 0,000 & & & \\
\hline EPS & 0,170 & 2,760 & 0,006 & 54,027 & 0,637 & 0,625 \\
\hline TAPS & 0,357 & 4,654 & 0,000 & $(0,000)^{*}$ & & \\
\hline
\end{tabular}

* Significant at 0,05 level

The result of regression presented in Table 1, shows that the Adjusted $\mathrm{R}^{2}$ which is 0,24 (significant at 0.05 level) in the pre-consolidated period, when firms were preparing and disclosing the individual financial statements (2000-2003), increased significantly and reached Adjusted R20,62 (significant at 0.05 level) during the post-consolidated period when companies started to prepare and disclose consolidated financial statements. That is, significant increase in explanatory power of Model 1 ( 0.38 increase in Adjusted $\mathrm{R}^{2}$ )during the postconsolidated period of 2006-2009, clearly indicatethe impact of financial information derived from consolidated financial statements (equity, net income and total assets) on the stock price as used proxy for performance in this study.On the other hand, in pre consolidated period (2000-2003), only the total assets of independent variables have an significant impact on stock price at 0,05 significance level. Along with the transition to consolidated reporting, equity and net income as well as total assets affect significantly the stock price at 0,05 level.

TABLE II Empirical Results for Regression Model 2

\begin{tabular}{|c|c|c|c|c|c|c|}
\hline $2000-2003$ & \multicolumn{6}{|c|}{$R_{i t+l}=\beta_{0}+\beta_{1} * B V P S_{i t}+\beta_{2} * E P S_{i t}+\beta_{3} * T A P S_{i t}+\varepsilon_{i t}$ (Model 2) } \\
\hline Variable & Beta & $\mathrm{t}$ & t Sig. & $\mathrm{F}$ & $\mathrm{R}^{2}$ & Adj. $R^{2}$ \\
\hline BVPS & $-0,095$ & $-0,636$ & 0,526 & & & \\
\hline EPS & 0,097 & 0,875 & 0,383 & 1,578 & 0,049 & 0,018 \\
\hline TAPS & $-0,089$ & $-0,789$ & 0,431 & $(0,156)^{*}$ & & \\
\hline $2006-2009$ & \multicolumn{6}{|c|}{$R_{i t+l}=\beta_{0}+\beta_{1} * B V P S_{i t}+\beta_{2} * E P S_{i t}+\beta_{3} * T A P S_{i t}+\varepsilon_{i t}$ (Model 2) } \\
\hline Variable & Beta & $\mathrm{t}$ & t Sig. & $\mathrm{F}$ & $\mathrm{R}^{2}$ & Adj. $R^{2}$ \\
\hline BVPS & 0,028 & 0,182 & 0,856 & & & \\
\hline EPS & $-0,054$ & $-0,553$ & 0,581 & 7,404 & 0,194 & 0,167 \\
\hline TAPS & $-0,077$ & $-0,595$ & 0,552 & $(0,000)^{*}$ & & \\
\hline
\end{tabular}

* Significant at 0,05 level 
The result of regression presented in Table 2, shows that the AdjustedR ${ }^{2}$ found to be 0,018 , is not significant at 0.05 levels in the pre-consolidated period of 2000-2003, during the period when firms were preparing and disclosing the individual financial statements. That is, the independent variables don't considerably explain differences in the level of firm stock returns before 2005 when individual financial statements were disclosed.On the other hand, the independent variables (equity, net income and total assets) in the model explain 0, 16 percent of aviation on stock returns (significantat 0,05 level) during the post consolidation period of 2006-2009, when consolidated financial statements were prepared and disclosed according to IFRS. With the transfer from individual to consolidated financial statements, the increase in $\operatorname{Adj} . \mathrm{R}^{2}(0,15)$ shows that the independent variables in multiple regression model reveal an increase in their impact on stock returns.

\section{Conclusion}

Theoretical arguments and conflicting research findings in the literature on relationship between consolidated financial statements and performance of companies suggest that the impact of the consolidated financial statements on the performance of companies may be positive or negative. In order tocontribute to the existing debate in literature, this study focused on the companies listed on the BIST, tested the relationship between consolidated financial statements and firm performance.

The test results which tend to reject the hypotheses "relationship between financial information derived from financial statements and performance (stock price and return) of companies listed on BİST İstanbul did not change with the transition to the consolidated financial reporting", would provide strong indication suggesting positive impact of the consolidated financial statements on performance of companies listed on BİST in Turkey. While these findings are different from some research findings in literature (Schiebel, 2006; Paananen, 2008; Paglietti, 2009; Klimczak, 2011; etc.), on line with the majority of research findings (Callao et al., 2007; Goncharov et al., 2009; Aharony et al., 2010; Suadiye, 2012; Müller, 2014; etc.). In addition, the results are consistent with the expectations of this study.

\section{References}

[1] A.Devalle, E. Onali, and R. Magarini, "Assessing the value relevance of accounting data after the introduction of IFRS in Europe," Journal of International Financial Management and Accounting, vol. 21(2), pp. 85-119, 2010. https://doi.org/10.1111/j.1467-646X.2010.01037.x

[2] A.Schiebel, "Value relevance of German GAAP and IFRS consolidated financial reporting: An empirical analysis of the Frankfurt Stock Exchange," Paper available at SSRN: http://ssrn.com/abstract=916103, 2006.

[3] A.Tiron-Tudor, and R. V. Ratiu, "How transparent are companies listed on the Bucharest Stock Exchange when disclose them consolidated financial statements," Annales Universitatis Apulensis Series Oeconomica, vol. 12(1), pp. 185-190, 2010.

[4] A.Türel, "The value relevance of IFRS: The case of Turkey," Acta Universitatis Danubius. Economica, vol. 5(1), pp. 119-128, 2010.

[5] B.Sultanoğlu, "UFRS'nin Borsa İstanbul'daki şirketlerin finansal tabloları üzerindeki etkisi: Finansal bilginin ihtiyaca uygunluğu ve finansal tablolar analizi," Unpublished PhD thesis, Başkent Üniv., Ankara, 2014.

[6] D.Dobija, and K. M. Klimczak, "Development of accounting in Poland: Market efficiency and the value relevance of reported earnings," The International Journal of Accounting, vol. 45(3), pp. 356-374, 2010. https://doi.org/10.1016/j.intacc.2010.06.010

[7] D.W. Collins, E. L. Maydew, and I. S. Weiss, "Changes in the value-relevance of earnings and book values over the past forty years," Journal of accounting and economics, vol. 24(1), pp. 39-67, 1997. https://doi.org/10.1016/S0165-4101(97)00015-3

[8] E.K. Jermakowicz, J. Prather-Kinsey, and I. Wulf, "The value relevance of accounting income reported by DAX-30 German Companies,"Journal of International Financial Management and Accounting, vol. 18(3), pp. 151-191, 2007. https://doi.org/10.1111/j.1467-646X.2007.01011.x

[9] G.Suadiye, "Value relevance of book value \& earnings under the local GAAP and IFRS: Evidence from Turkey,"Ege Akademik Bakış, vol. 12(3), pp. 301-310, 2012.

https://doi.org/10.21121/eab.2012319519 
[10] I.Goncharov, J. R. Werner, and J. Zimmermann, "Legislative demands and economic realities: Company and group accounts compared," The International Journal of Accounting, vol. 44(4), pp. 334-362, 2009. https://doi.org/10.1016/j.intacc.2009.09.006

[11] J.Aharony, R. Barniv, and H. Falk, "The impact of mandatory IFRS adoption on equity valuation of accounting numbers for security investors in the EU," European Accounting Review, vol. 19(3), pp. 535-578, 2010. https://doi.org/10.1080/09638180.2010.506285

[12] J.A. Ohlson, "Earnings, book values, and dividends in security valuation," Contemporary Accounting Research, vol. 11(2), pp. 661-687, 1995. https://doi.org/10.1111/j.1911-3846.1995.tb00461.x

[13] J.B. Khanagha, "Value relevance of accounting information in the United Arab Emirates," International Journal of Economics and Financial Issues, vol. 1(2), pp. 33-45, 2011.

[14] J.Francis, and K. Schipper, "Have financial statements lost their relevance?," Journal of Accounting Research, vol. 37(2), pp. 319-352, 1999. https://doi.org/10.2307/2491412

[15] K.M. Klimczak, "Market reaction to mandatory IFRS adoption: Evidence from Poland," Accounting and Management Information Systems, vol. 10(2), pp. 228-248, 2011.

[16] M.Agostino, D. Drago, and D. B. Silipo, "The value relevance of IFRS in the European banking industry," Review of Quantitative Finance and Accounting, vol. 36(3), pp. 437-457, 2011 https://doi.org/10.1007/s11156-010-0184-1.

[17] M.Hung, and K. R. Subramanyam, "Financial statement effects of adopting international accounting standards: The case of Germany," Review of Accounting Studies, vol. 12(4), pp. 623-657, 2007. https://doi.org/10.1007/s11142-007-9049-9

[18] M.Paananen, “The IFRS adoption's effect on accounting quality in Sweden,” Working Paper, 2008.

[19] M.Paananen, and H. Lin, "The development of accounting quality of IAS and IFRS over time: The case of Germany," SSRN Working Paper Series, 2008.

[20] P.D. Easton, and T. S. Harris, "Earnings as an explanatory variable for returns," Journal of Accounting Research, vol. 29(1), pp. 19-36, 1991. https://doi.org/10.2307/2491026

[21]P.Paglietti, "Earnings management, timely loss recognition and value relevance in Europe following the IFRS mandatory adoption: Evidence from Italian listed companies,"Economia Aziendale Online, vol. 4, pp. 97-117, 2009.

[22] R.Alpar, "Uygulamalı çok değişkenli istatistiksel yöntemler," 3st ed. Ankara, Detay Yayıncılık, 2011.

[23] S. Callao, J. I. Jarne, and J. A. Lainez, "Adoption of IFRS in Spain: Effect on the comparability and relevance of financial reporting," Journal of International Accounting, Auditing and Taxation, vol. 16(2), pp. 148-178, 2007. https://doi.org/10.1016/j.intaccaudtax.2007.06.002

[24] S.Kargin, "The impact of IFRS on the value relevance of accounting information: Evidence from Turkish firms," International Journal of Economics and Finance, vol. 5(4), pp. 71-80, 2013. https://doi.org/10.5539/ijef.v5n4p71

[25] Ş.Kalaycı, SPSS uygulamalı çok değişkenli istatistik teknikleri, 2 st ed. Asil Yayın Dağıtım, 2006.

[26] V.Capkun, A. Cazavan Jeny, T. Jeanjean, and L. A. Weiss, "Earnings management and value relevance during the mandatory transition from local GAAPs to IFRS in Europe," Available at SSRN 1125716, 2008.

[27] V.O. Müller, "The impact of IFRS adoption on the quality of consolidated financial reporting," Procedia-Social and Behavioral Sciences, vol. 109, pp. 976-982, 2014.

https://doi.org/10.1016/j.sbspro.2013.12.574 